\title{
Benchmarks
}

\section{Pit-Stop PCR: An Approach to Increase Final Product Yield of Multiplex PCR}

\section{BioTechniques 26:638-639 (April 1999)}

Since the development of the polymerase chain reaction (PCR), many strategies have been designed to amplify one or more specific DNA sequences with a single set of oligonucleotide primers. Multiplex PCR is a strategy to amplify simultaneously either two or multiple DNA targets sequences in a single reaction (4). A variety of reaction conditions must be used to optimize multiplex-PCR strategies. However, increasing the number of primer pairs in a single PCR increases the chance of obtaining spurious amplification products. In a number of cases PCR primer pairs do not maintain their specificity when combined into a single reaction mixture using the amplification conditions established for the individual pairs (3), and some PCR products are produced at greater efficiencies than others. An approach to solving this problem is to change primer concentrations, which could prove to be insufficient. In this report, a simple and efficient modification is described to improve the signal in three different experimental conditions of multiplex PCR. We propose naming this strategy pit-stop PCR.

A number of multiplexing protocols, e.g., for bovine embryo sexing by PCR using bovine Y-chromosome-specific primers and the co-amplification of bovine autosomal primers as an internal control for specimen integrity have been described $(8,9)$. When using bovine autosomal control primers in the described reaction, the presence of two bands (one male-specific and one autosomal bovine-specific) is interpreted to be a male embryo; whereas, when the male-specific band is absent and the bovine-specific band visible, the embryo is considered to be a female. The lack of the two bands indicates the absence of embryonic DNA in the sample, which is considered a dubious diagnosis. Thus, using this control, sex misidentification did not occur (exclud- ing the false female results). However, when no autosomal control primers are used, the sample showing one amplified band is considered as a male, and when no male-specific band is detected, the embryo is considered to be a female one. In this case, the presence of no amplified products could also indicate the absence of embryonic DNA in the sample. In spite of the use of a control primer pair being helpful for avoiding the occurrence of false sex identification, many autosomal oligonucleotides tested seem to interfere with the amplification of the Y-chromosome-specific sequence, especially when a very dilute amount of template was used $(2,8)$.

In this work, a multiplex-PCR protocol for sex determination of bovine embryos was tested. The pair of bovine Ychromosome-specific oligonucleotides (6) was designed from a bovine repetitive sequence of $\mathrm{Y}$ chromosome to amplify a 175-bp product. The pair of control bovine-specific oligonucleotide primers (8) was designed to amplify a 216-bp fragment of a 1399-bp-long repeated unit of bovine 1.715 satellite DNA. The male and female bovine DNAs used were isolated from heparinized peripheral blood (7) or from embryonic cells (5). The PCR was performed in $0.5-\mathrm{mL}$ microcentrifuge tubes containing a final concentration of $10 \mathrm{mM}$ Tris- $\mathrm{HCl}, \mathrm{pH} 8.3,50 \mathrm{mM}$ $\mathrm{KCl}, 1.5 \mathrm{mM} \mathrm{MgCl} 2,100 \mu \mathrm{M}$ of each dNTP (Boehringer Mannheim GmbH, Mannheim, Germany), $0.4 \mu \mathrm{g}$ bovine serum albumin (BSA) (nuclease-free; Cenbiot, Porto Alegre, RS, Brazil), 0.6 ng each of oligonucleotide primer (Biodynamics, Buenos Aires, Argentina), 1 U per assay of Taq DNA Polymerase (Cenbiot) and male or female bovine DNA as template. Mineral oil (40-50 $\mu \mathrm{L}$; Sigma, St. Louis, MO, USA) was pipetted on top of the reaction mixture $(25 \mu \mathrm{L})$ and incubated at $94^{\circ} \mathrm{C}$ for 5 min in a DNA Thermal Cycler (PE Biosystems, Foster City, CA, USA). The PCR program consisted of 40 cycles at $94^{\circ} \mathrm{C}$ for $60 \mathrm{~s}, 56^{\circ} \mathrm{C}$ for $30 \mathrm{~s}$ and $72^{\circ} \mathrm{C}$ for $60 \mathrm{~s}$, followed by a final extension at $72^{\circ} \mathrm{C}$ for $8 \mathrm{~min}$. The PCR products were analyzed on agarose gels.

Optimization involved varying enzyme concentration, buffer composition and cycle parameters of the multiplex-PCR protocol. Nevertheless, some
PCR products were produced at greater efficiency than others, which is consistent with a very weak or null amplification of the Y-specific fragment commonly observed in bovine DNA male samples. To solve this problem, either the primer concentrations were reduced for the PCR products that produced the greatest yields or the primer concentrations were increased for PCR products with the lowest yields. However, these latter approaches resulted in no improvement in signal of the lowestyielding PCR product.

A modification was then introduced in the multiplex-PCR strategy that consisted of including the pair of bovinespecific control primers, which produced the greatest amount of PCR product, into tubes containing the reaction mixture only after several cycles. The best results of this pit-stop PCR strategy were obtained when the pair of bovine-specific control primers was added after the fourth cycle of the DNA amplification (Figure 1).

This pit-stop PCR strategy was also used to solve similar problems with two other distinct multiplex PCRs as described elsewhere $(1,10)$. The weaker signals produced by $(i)$ the $f e m A$ gene PCR product after the co-amplification

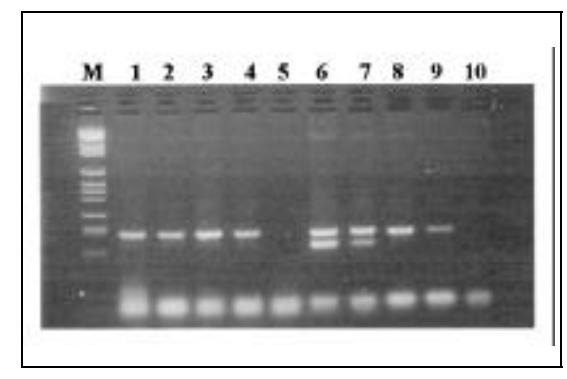

Figure 1. Comparison of standard multiplex and pit-stop PCRs. Electrophoresis in $2.5 \%$ agarose gel stained with $0.25 \mu \mathrm{g} / \mathrm{mL}$ ethidium bromide shows the amplification products of bovine DNA isolated from heparinized peripheral blood. Lanes 1-5 show the PCR products when both primer pairs were added simultaneously before the PCR (standard multiplex PCR). Lanes 6-10 show the amplification products of a pitstop PCR including addition of the pair of bovinespecific control primers into tubes containing the reaction mixture after the fourth cycle of the DNA amplification. M, $0.25 \mu \mathrm{g}$ DNA molecular-weight marker VI (Boehringer Mannheim); lanes 1 and 2, 6 and 7 contained 20 and 5 pg of bovine male DNA, respectively; whereas lanes 3 and 4, 8 and 9 contained 20 and $5 \mathrm{pg}$ of bovine female DNA, respectively. Lanes 5 and 10 show control PCRs without DNA. 
of mecA and femA genes from Staphylococcus aureus species and (ii) the human papillomavirus (HPV) L1 region after co-amplification of HPV L1 and $\beta$-globin DNAs were overcome by the PCR strategy presented here (data not shown).

The results we present show that addition of the primer pair that produced the greatest yield of PCR product after a few cycles of a specific DNA amplification protocol improves the signal strength of the lowest-yielding one. This avoids masking that occurred when both primer pairs were added before the PCR. It is important to consider that in the three examples of multiplex PCR mentioned, the pit-stop PCR was used only with two primer pairs and each one needed a specific optimization of cycle numbers preceding the addition of primer pair with the greatest yield of PCR product.

\section{REFERENCES}

1.Bauer, H.M. and M.M. Manos. 1993. PCR detection of genital human papillomavirus, $p$. 407-413. In D.H. Persing, T.F. Smith, F.C. Tenover and T.J. White (Eds.), Diagnostic Molecular Microbiology: Principles and Applications. American Society of Microbiology, Washington, DC.

2.Bredbacka, P., R. Velmala, J. Peippo and K. Bredbacka. 1994. Survival of biopsied and sexed bovine demi-embryos. Theriogenology 41:1023-1031.

3.Chamberlain, J.S. and J.R. Chamberlain. 1994. Optimization of multiplex PCRs, p. 3846. In K.B. Mullis, F. Ferré and R.A. Gibbs (Eds.), The Polymerase Chain Reaction. Birkhäuser, Boston.

4.Chamberlain, J.S., R.A. Gibbs, J.E. Ranier and C.T. Caskey. 1989. Multiplex PCR for the diagnosis of Duchenne muscular dystrophy, p. 272-271. In M. Innis, D. Gelfand, J. Sninski and T. White (Eds.), PCR Protocols: A Guide to Methods and Applications. Academic Press, Orlando.

5.Lopes, R.F.F., J.L. Rodrigues, R.J. Chebel, H.M.M. Maia, J.A.S. Perseu, C. Termignoni and G.M. Stoll Rial. 1992. Survival of bovine embryos after micromanipulation for sex determination using the polymerase chain reaction (PCR). Proceedings of the 12th International Congress on Animal Reproduction 2:712-714.

6.Macháty, Z., A. Páldi, L. Solti and G. Vajta. 1992. Blastomere biopsy and sex determination in bovine IVF embryos. Proceedings of the 12th International Congress on Animal Reproduction 2:715-717.

7.Miller, S.A., D.D. Dykes and H.F. Polesky. 1988. A simple salting out procedure for extracting DNA from human nucleated cells. Nucleic Acids Res. 16:1215.
8.Peura, T., J-M. Hyttinen, M. Turunen and J. Jänne. 1991. A reliable sex determination assay for bovine preimplantation embryos using the polymerase chain reaction. Theriogenology 35:547-555.

9.Thibier, M. and M. Nibart. 1995. The sexing of bovine embryos in the field. Theriogenology 43:71-80.

10.Vannuffel, P., J. Gigi, H. Ezzedine, B. Vandercam, M. Delmee, G. Wauters and J-L. Gala. 1995. Specific detection of methicillinresistant Staphylococcus species by multiplex PCR. J. Clin. Microbiol. 33:2864-2867.

Address correspondence to Dr. Rui Fernando Felix Lopes, Centro de Biotecnologia, Universidade Federal do Rio Grande do Sul, Cx Postal 15005, Porto Alegre-RS, CEP 91501-970, Brasil. Internet: rfflopes@dna.cbiot.ufrgs.br

Received 23 September 1998; accepted 9 December 1998.

Rui Fernando Felix Lopes, José Procópio Moreno Senna, Jocelei Maria Chies and José Luiz Rodrigues Universidade Federal do Rio Grande do Sul Porto Alegre-RS, Brasil

\section{Adaptation of Inverse PCR to Generate an Internal Deletion}

BioTechniques 26:639-641 (April 1999)

Alterations of DNA sequences are frequently required for procedures such as generating a mutation for promoter analysis, dissecting a functional domain and recombinant protein engineering. In general, sequence alteration can involve addition, deletion and/or point mutation. The most convenient way to generate an internal deletion is to use two restriction enzymes that will remove an internal fragment. However, in most cases, convenient enzyme sites are not available for use near the sequence to be deleted. Another approach is oligonucleotide-directed mutagene- 